\title{
Assessing Minerals Status of Dairy Animals in South-West Zone of Punjab
}

\author{
B. M. Bhanderi", M.R. Garg and P.L. Sherasia
}

Animal Nutrition Group, National Dairy Development Board, Anand-388 001 (Gujarat), India

\begin{abstract}
A study was carried out to assess dietary macro and micro-minerals status of milch buffaloes in Firozpur, Mansa and Muktsar districts, under South-West Zone of Punjab. Feeds and fodder samples were collected at random from various locations, following standard sampling procedure. The average calcium (Ca) content in straws was low $(0.28 \%)$. Green fodders such as berseem $(1.88 \%)$, chikori $(1.26 \%)$, oat $(0.45 \%)$, rye grass $(0.56 \%)$ and mustard $(1.34 \%)$ were found to be rich source of $\mathrm{Ca}$. Concentrate feed ingredients such as mustard cake $(0.68 \%)$, cottonseed cake $(0.23 \%)$, rice polish $(0.11 \%)$ and wheat flour $(0.053 \%)$ were high to low in $\mathrm{Ca}$. The phosphorus $(\mathrm{P})$ content in crop residues and green fodders was 0.08 and 0.47 per cent, respectively. Concentrate feed ingredients were high $(0.78 \%)$ in $P$. The magnesium content in roughages and concentrate feed ingredients was 0.31 and 0.41 per cent, respectively. The sodium content was low in concentrate ingredients $(0.043 \%)$ and dry fodder $(0.065 \%)$, but high in green fodder $(0.63 \%)$. The sulphur content was adequate in green fodder $(0.32 \%)$, whereas, crop residues $(0.16 \%)$ and concentrate ingredients $(0.18 \%)$, except mustard cake $(0.33 \%)$ were deficient in sulphur; hence, its supplementation was necessary in the ration of milch animals. The cobalt was deficient in the diet of animals to the extent of 45 per cent; however, iron (average level $>500 \mathrm{ppm}$ ) and manganese (average level $>60 \mathrm{ppm}$ ) in most of the feed ingredients were adequate, with traditional feeding system. The average copper content was very low in straws $(2.94 \mathrm{ppm})$ and moderate in green fodders (11.93 $\mathrm{ppm})$. Concentrate ingredients were again low in copper $(9.19 \mathrm{ppm})$. Zinc was deficient in most of the feedstuffs (average level<38 ppm) and needed to be supplemented for proper productive and reproductive functions. From the present study, it was apparent that the levels of certain minerals such as calcium, phosphorus, sulphur, zinc, copper and cobalt were inadequate, as per the prevailing feeding practices and requirement of buffalo yielding $10 \mathrm{~kg}$ milk $(6 \%$ fat) per day. However, the levels of some other mineral elements such as magnesium, sodium, potassium, iron, manganese and selenium were found to be adequate in the South-West Zone of Punjab.
\end{abstract}

Keywords: Calcium, Phosphorus, Sulphur, Copper, Zinc, Cobalt, Buffalo, Punjab.

\section{INTRODUCTION}

Mineral elements have been recognized for many years as essential dietary nutrients for animals and play an important role in normal health, growth, productive and reproductive performance of livestock [1]. Farm animals derive their mineral requirements mainly from the feedstuffs offered to them as little or no mineral mixture is supplemented under field conditions [2]. Deficiency of minerals is frequently encountered in livestock ration, in most of the tropical countries, unless supplemented with deficient minerals [3]. The soil concentration of minerals keeps on changing due to pressure on land for maximum crop production, fertilizer application, rain and natural calamities. As a result, the mineral content of the feed and fodders may be altered thereby affecting the mineral status of animals [4-5]. A comprehensive knowledge of the level of micronutrients in feeds and fodder of a particular area is essential for balancing dietary mineral supply and formulating area specific mineral mixture. Therefore, the present investigation was carried out to assess the mineral status of dairy animals in SouthWest Zone of Punjab.

*Address correspondence to this author at the Animal Nutrition Group, National Dairy Development Board, Anand-388 001 (Gujarat), India; Tel: +0091-2692226270; E-mail: bhanderi@nddb.coop

\section{MATERIALS AND METHODS}

At random, one centrally located village from each taluka of Firozpur, Mansa and Muktsar districts from South-West Zone of Punjab was selected, for taking representative samples of feeds and fodder. Within the village, help was sought from the village level milk producer societies and District Cooperative Milk Producers' Unions, for identification of 4 to 5 farmers. Two dimensional survey technique was adopted by taking village as an unit for collection of feed samples in different talukas of Firozpur, Mansa and Muktsar districts, to identify the mineral deficiency or excess, to judge the magnitude of the problem and to indicate its origin [6]. The recorded parameters were number of livestock, land area, irrigated facilities, fodder and other crops being grown etc. In identification of farmers, land location was considered essentially, one each from Northern, Eastern, Western and Southern directions, to cover soil types on each side of the selected village.

Further, information regarding the amount and types of feeds and fodder being offered to the animals, actual rate of daily feed intake and milk yield of individual animals was collected from individual farmer. The dry matter intake (DMI) of animals was based on actual measurements made during the sample collection. Daily DMI of animals $(n=126)$ was ranging from 11.10 to $18.20 \mathrm{~kg}(13.50 \pm 0.45 \mathrm{~kg})$. Total intake was 
compared against the requirement on dry matter basis [7-8], so as to identify quantitative deficiency, sufficiency or even excess. The data were analyzed statistically as per Snedecor and Cochran [9].

Composite samples of green fodder, dry fodder, individual concentrate ingredients and the compound cattle feed (concentrate mixture) were collected from all over the surveyed area. Green fodder samples were dried in oven at $80^{\circ} \mathrm{C}$ for $24 \mathrm{hrs}$ and subsequently ground $(1 \mathrm{~mm})$. Ground samples of concentrate and fodder were stored in airtight bags until analysis. Samples were prepared and digested using $5 \mathrm{ml}$ concentrated $\mathrm{HNO}_{3}$ plus $1 \mathrm{ml}$ concentrated $\mathrm{HCl}$ by microwave digestion method for preventing evaporation of volatile elements and total volume of mineral extracts was made to $25 \mathrm{ml}$ with deionized water. All the samples were analyzed for calcium (Ca), phosphorus $(P)$, magnesium $(\mathrm{Mg})$, sodium $(\mathrm{Na})$, potassium $(\mathrm{K})$, sulphur $(\mathrm{S})$, copper $(\mathrm{Cu})$, zinc $(\mathrm{Zn})$, manganese $(\mathrm{Mn})$, iron $(\mathrm{Fe})$, cobalt $(\mathrm{Co})$, molybdenum (Mo) and selenium (Se), using Inductively Coupled Plasma-Optical Emission Spectroscopy (Perkin-Elmer, OPTIMA - $3300 \mathrm{RL})$.

\section{RESULTS AND DISCUSSION}

\section{Feeding and Management}

Wheat and rice straws were the main roughage available for feeding dairy animals. However, the farmers were found to be reluctant to feed rice straw, it was fed only when wheat straw was not available in sufficient quantity. Berseem (Trifolium alexandrinum), lucerne (Megicago sativa), oat (Avena sativa), maize were the major green fodder available and were being fed liberally to dairy animals in the villages of SouthWest Zone. In addition, rye grass, chikori, mustard green and bajra green were also being fed to the animals along with other green fodders [10]. Amongst oil cakes, cottonseed and mustard cakes were the popular protein supplements and were fed as the sole concentrate to lactating buffaloes even they were fed adequate green fodder. Interestingly, it was observed that feeding of wheat flour to the milking animals is common in the surveyed area. In addition, it was noticed that farmers were using moong chunni and rice polish as concentrate supplements. Compound cattle feed was fed along with other concentrate ingredients mixed with chaffed green and dry fodder in the form of 'sanni'. Progressive milk producers were supplementing the ration of dairy animals with appropriate mineral mixture and common salt.

\section{Macro and Micro Mineral Profiles of Feeds and Fodder}

The profile of various macro and micro minerals in the feeds and fodder is presented in Table 1. Wheat straw was moderate in $\mathrm{Ca}(0.31 \%)$ and deficient in $\mathrm{P}$ $(0.10 \%)$, whereas, paddy straw was low in Ca $(0.25 \%)$ and $\mathrm{P}(0.06 \%)$. The $\mathrm{Ca}$ content of berseem fodder $(1.88 \%)$, lucerne fodder $(1.50 \%)$, chicory leaves $(1.26 \%)$ and mustard fodder $(1.34 \%)$ was higher than the rest of the feed stuffs. Oat fodder $(0.45 \%)$ and rye grass $(0.56 \%)$ was also good source of $\mathrm{Ca}$. Among the protein rich ingredients, mustard cake (Brassica napus) was good source of $\mathrm{Ca}(0.68 \%)$ and $\mathrm{P}(0.95 \%)$, whereas, cottonseed cake was good source of $P$ $(0.72 \%)$ but poor in $\mathrm{Ca}(0.23 \%)$. Compound feed contained 0.92 per cent $\mathrm{Ca}$ and 1.35 per cent $\mathrm{P}$. Wheat flour was deficient in $\mathrm{Ca}(0.053 \%)$ and adequate in $\mathrm{P}$ $(0.38 \%)$ content. Amongst the other feeds, moong chunni was moderate source of $\mathrm{Ca}(0.47 \%)$ and $\mathrm{P}$ $(0.30 \%)$, while rice polish was very good source $P$ $(1.57 \%)$ but very low in $\mathrm{Ca}(0.11 \%)$ content.

The magnesium level as estimated in the wheat straw samples was adequate (Table 1). Amongst green fodder, lucerne green $(0.53 \%)$ had the highest $\mathrm{Mg}$ content followed by berseem green $(0.50 \%)$, rye grass $(0.28 \%)$ and oat fodder $(0.22 \%)$, showing that considerable quantities of $\mathrm{Mg}$ were available to the livestock requirement point of view. Mustard cake $(0.42 \%)$, cottonseed cake $(0.49 \%)$, moong chunni $(0.46 \%)$, rice polish $(0.54 \%)$ were good source of $\mathrm{Mg}$. Wheat flour was found to be a poor source of $\mathrm{Mg}$ $(0.15 \%)$. Compound feed contained $0.75 \% \mathrm{Mg}$, a level much higher than the requirements. Magnesium is considered as an important factor in occurrence of grass tetany (Hypomagnesaemic tetany) in animals [11] and is necessary for all phosphate transfer reactions [12].

The sodium content was low in paddy straw $(0.03 \%)$, whereas, wheat straw, leguminous fodders, oat green and rye grass contained high $\mathrm{Na}$ (Table 1). Compound feed had an appreciate quantity of sodium to the extent of 0.85 per cent, because of added common salt in the raw materials during manufacturing. Amongst oil cakes, mustard cake was fair in $\mathrm{Na}$ content $(0.081 \%)$, whereas, cottonseed cake was moderate in $\mathrm{Na}(0.059 \%)$. Sodium content in other concentrate ingredients like moong chunni $(0.03 \%)$, rice polish $(0.02 \%)$ and wheat flour $(0.026 \%)$ was lower than the respective critical levels. High level of $\mathrm{K}$ was found in all dry and green forages. Similar findings were also 


\begin{tabular}{|c|c|c|c|c|c|c|c|c|c|c|c|c|c|c|c|c|}
\hline$\ddot{3}$ & & 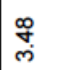 & ্ָ & مٌ & 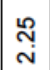 & 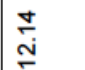 & $\stackrel{n}{d}$ & $\underset{\infty}{\mp}$ & $\begin{array}{l}0 \\
0 \\
\stackrel{0}{0}\end{array}$ & $\begin{array}{l}\text { 苟 } \\
\text { in }\end{array}$ & 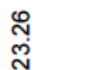 & \begin{tabular}{|l}
$\infty$ \\
$\infty$ \\
$\omega$
\end{tabular} & 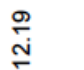 & $\mid \begin{array}{l}0 \\
0 \\
\omega\end{array}$ & 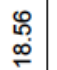 & 芯 \\
\hline $\bar{N} \overline{\underline{E}}$ & 일 & 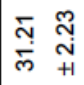 & 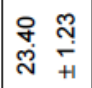 & $\begin{array}{cc}\mathcal{F} & \hat{\infty} \\
\bar{n} & \underset{+}{+1}\end{array}$ & $\begin{array}{l}\dot{T} \\
\dot{q}\end{array}$ & $\begin{array}{ll}0 & 8 \\
\stackrel{0}{n} & 0 \\
& 0 \\
+1\end{array}$ & 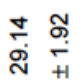 & 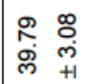 & $\stackrel{\stackrel{N}{d}}{\text { d }}$ & 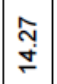 & 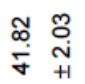 & 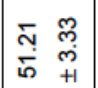 & 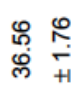 & \begin{tabular}{|l|}
$\stackrel{0}{0}$ \\
$\stackrel{\infty}{\infty}$
\end{tabular} & 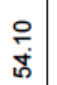 & 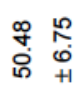 \\
\hline
\end{tabular}

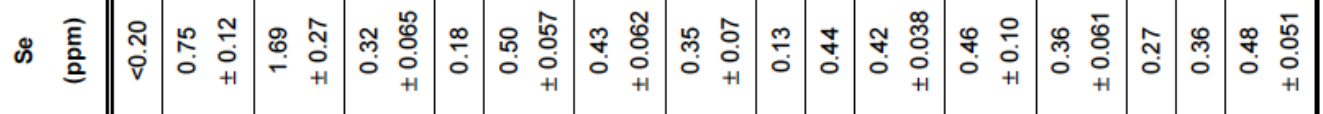

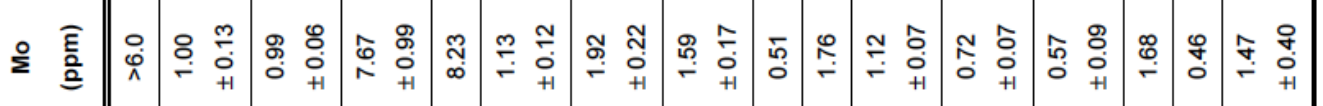

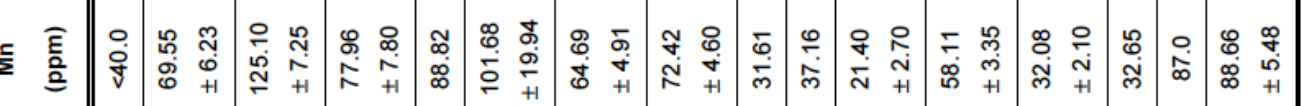

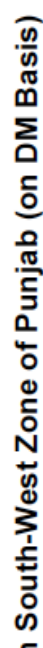

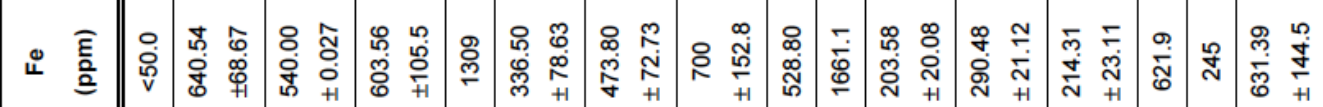

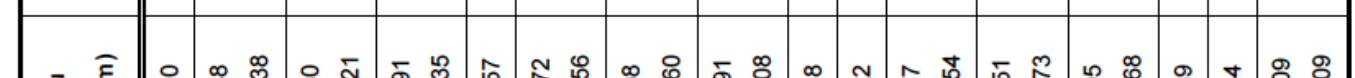

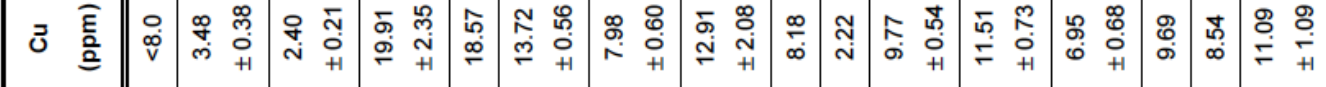

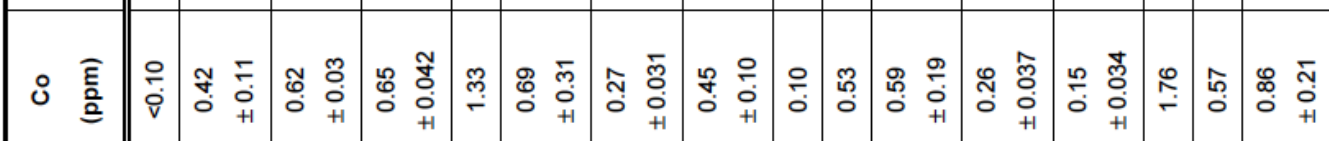

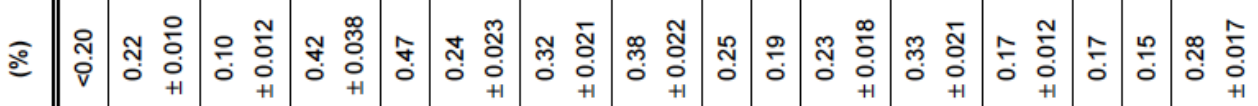

$x$ ¿

$\frac{0}{8}$

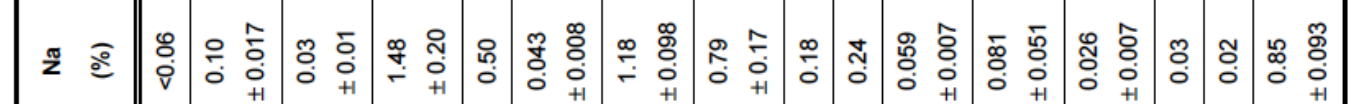

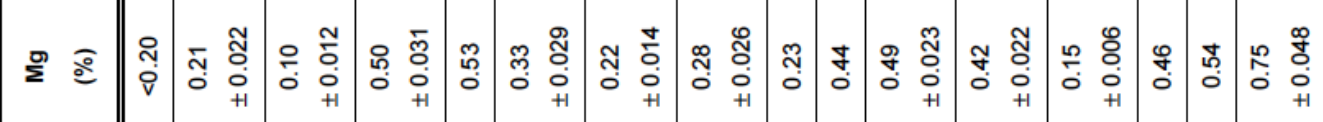

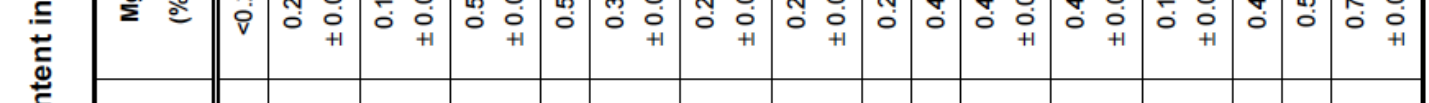

o

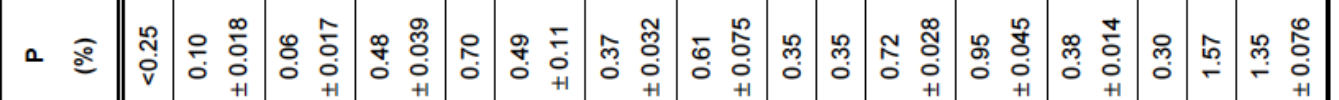

\begin{tabular}{|c|c|c|c|c|c|c|c|c|c|c|c|c|c|c|c|c|}
\hline $\begin{array}{l}\text { ¿ } \\
\text { षँّ }\end{array}$ & 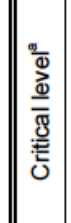 & 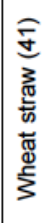 & 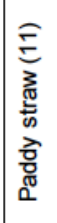 & 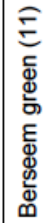 & 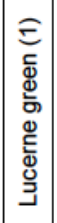 & 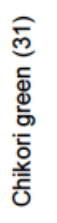 & 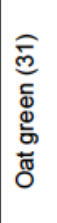 & 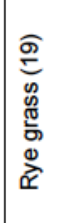 & 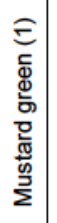 & 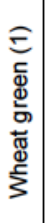 & 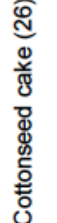 & 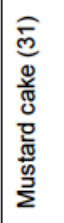 & 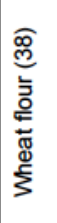 & 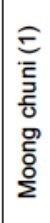 & 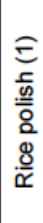 & 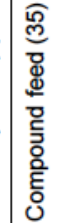 \\
\hline
\end{tabular}


reported by Garg et al. [13] and Singh et al. [14]. Like roughages, concentrate ingredients were also having high level of $\mathrm{K}$ than the critical level (Table 1) except wheat flour $(0.53 \%)$. From the Table 1 , it is also clear that potassium content in roughages was higher than that of the concentrate ingredients which was similar to the findings of Garg et al. [13]. However, excessive levels of $\mathrm{K}$ may be a contributory factor for the risk of milk fever.

The sulphur content was low in paddy straw $(0.10 \%)$, whereas, wheat straw $(0.22 \%)$ and green forages were found to be good source of $\mathrm{S}$. Mustard cake $(0.33 \%)$, cottonseed cake $(0.23 \%)$ and compound feed $(0.28 \%)$ were good source of $S$ as compared to wheat flour $(0.17 \%)$, moong chunni $(0.17 \%)$ and rice polish $(0.15 \%)$. The variation in $S$ contents of plants depends on amounts of $S$ in plant proteins in the form of S-containing amino acids [15].

From the survey, it was found that moong chunni contained highest Co content (1.76 ppm), followed by lucerne green (1.33 ppm) among all the feedstuffs. On the other hand mustard fodder was having the lowest cobalt content $(0.10 \mathrm{ppm})$. Commonly available feed ingredients in this zone were found to be deficient in cobalt from animal requirement point of view (Table 1 ).

Copper content was recorded constantly low in wheat straw (3.48 ppm) and paddy straw (2.40 ppm) samples. Berseem green (19.91 ppm), lucerne green (18.57 ppm), chikori green (13.72 ppm), rye grass (12.91 ppm) were found to be good in $\mathrm{Cu}$ content, whereas, oat fodder (7.98 ppm) and mustard green (8.18 ppm) was marginal in $\mathrm{Cu}$ level. The $\mathrm{Cu}$ level was very low in wheat green (2.22 ppm). Mustard cake (11.51 ppm), cottonseed cake (9.77 ppm), moong chunni (9.69 ppm), rice polish (8.54 ppm) and compound feed was moderate in $\mathrm{Cu}$ content. Copper deficiency in feeds and fodder was also observed by Das et al. [16] in West Bengal and Tiwari et al. [17] in Haridwar district of Uttarakhand. Dietary copper requirement is $10 \mathrm{ppm}$ and adequate $\mathrm{Cu}$ content is essential to reduce mammary gland infection (mastitis) and to increase the neutrophil killing [18]. Copper deficiency is associated with early embryonic death, reduced ovarian activity, decreased conception rate, increased incidence of retained placenta and increased difficulty in calving [19-20]. Therefore, supplementation of $\mathrm{Cu}$ is essential for the dairy animals.

Most of the feeds and fodders offered to the livestock contained reasonable amount of iron $(>200$ $\mathrm{ppm})$. The $\mathrm{Fe}$ concentration was highest in wheat green (1661.1 ppm) followed by lucerne fodder (1309 $\mathrm{ppm})$. Even straw samples were quite rich in iron (640.5 ppm). Among oil cakes, mustard cake (290 ppm) contained higher Fe than cottonseed cake (203.6 $\mathrm{ppm})$. The iron concentration in the majority of the feeds and fodders was very high and could probably affect the copper absorption and metabolism [21-22].

Wheat straw contained around $69.5 \mathrm{ppm} \mathrm{Mn}$ (Table 1). However, higher $\mathrm{Mn}$ level was found in berseem green (77.96 ppm), lucerne green (88.82 ppm), chikori green (101.68 ppm). The Mn content of oat green (64.69 ppm) and rye grass (72.42 ppm) was comparable with that of wheat straw. Cottonseed cake contained the lowest Mn level (21.40 ppm) amongst all the feedstuffs; whereas, mustard cake contained comparatively higher level of $\mathrm{Mn}(58.11 \mathrm{ppm})$. Wheat flour (32.08 ppm) and moong chunni (32.65 ppm) were low in $\mathrm{Mn}$ content. Compound feed contained sufficiently higher level of $\mathrm{Mn}$ (88.66 ppm) to meet the dietary requirement of the animals.

The molybdenum levels as estimated in most of the feedstuffs were within the safe limit $(<6.0 \mathrm{ppm})$, except berseem and lucerne green (Table 1). When feedstuffs with high Mo content were incorporated in the ration of the animals, the copper supplementation must be regular and most frequent [4]. Therefore, $\mathrm{Cu}$ supplementation was needed when berseem green alone was fed as green fodder due to its high Mo content (7.67 ppm). Miltimore and Mason [23] stated that a $\mathrm{Cu}$ : Mo ratio below 2.0 would be expected to cause conditioned $\mathrm{Cu}$ deficiency in cattle. Most of the feedstuffs contained Mo level within safe limit and gave Co: Mo ratio wider than 5.0 .Mo levels of 5 to $6 \mathrm{ppm}$ inhibit $\mathrm{Cu}$ storage and produce signs of molybdenosis [12]. Even $2 \mathrm{ppm}$ or less Mo can be toxic, if forage copper is sufficiently low [22, 24]. In case of ruminants, Mo reacts with sulphur in the rumen and forms mono-, di-, tri- and tetra-thiomolybodates. Thiomolybodates can cause $\mathrm{Cu}$ deficiency by reacting with dietary $\mathrm{Cu}$ in the gastro-intestinal tract and making it unavailable for absorption and utilization [25].

The selenium content of wheat straw was $0.75 \mathrm{ppm}$, whereas, paddy straw contained higher level of $\mathrm{Se}$ (1.69 ppm). However, Se content was recorded lower in berseem green $(0.32 \mathrm{ppm})$ and oat fodder $(0.43$ ppm) compared to straws. Oil cakes and compound feed contained around $0.45 \mathrm{ppm} \mathrm{Se}$, whereas, moog chunni $(0.27 \mathrm{ppm})$ and rice polish $(0.36 \mathrm{ppm})$ contained 
comparatively lower level of Se. Minimum requirements of dietary Se, for all classes of livestock ranges from 0.10 to $0.30 \mathrm{ppm}$ [12]. Accepting the minimum requirements of $0.30 \mathrm{ppm} \mathrm{Se}$, which is the level considered adequate for preventing deficiency in dairy cattle [26], most of the feeds and fodders studied would satisfy the requirements of Se. Therefore, its supplementation in the ration is not advocated.

Zinc was found to be deficient in almost all the dry roughages, particularly wheat straw (31.20 ppm) and paddy straw $(23.40 \mathrm{ppm})$. Zinc deficiency in feed resources in many geographical zones of India has been reported by Ramana et al. [27] and Garg et al. [28]. Amongst the green forages, chikori green (72.50 ppm) had the highest $\mathrm{Zn}$ content followed by berseem green (51.42 ppm), rye grass (39.79 ppm), oat green (29.14 ppm) and mustard green (24.25 ppm). Mustard cake (51.21 ppm) was found to be better in terms of $\mathrm{Zn}$ content than that of cottonseed cake (41.82 ppm). $\mathrm{Zn}$ content of other concentrates was varied from 28.10 ppm to $54.48 \mathrm{ppm}$ (Table 1). Zinc functions in the immune system through energy production, protein synthesis, stabilization of membranes against bacterial endotoxins, maintenance of lymphocyte replication and antibody production [29-30]. In reproduction, zinc has major role to play as inadequate $\mathrm{Zn}$ levels have been associated with decreased fertility, abnormal estrus, abortion and altered myometrial contractibility with prolonged labor [31-32].

\section{Macro and Micro Minerals Intake by Buffaloes}

A buffalo yielding $10 \mathrm{~kg}$ milk per day with $6 \%$ fat was taken as a standard for the area of the study. The feeds and fodders available in the area when fed as per diet formulation given in the Table 2 , would provide $54.30 \mathrm{~g} \mathrm{Ca}$, whereas, the requirement of $\mathrm{Ca}$ for an animal was $64.50 \mathrm{~g}$, showing a clear deficiency. Under such condition, if the deficiency was not supplemented, milk production is likely to be affected and freshly calved animals may suffer from milk fever [3]. The estimated value of phosphorus from the feedstuffs was $40.77 \mathrm{~g}$ against the daily requirement of $42.80 \mathrm{~g}$ for a buffalo yielding $10 \mathrm{~kg}$ milk, showing a deficiency of 2.03 $\mathrm{g}$ per day (Table 2). Furthermore, bioavailability of $\mathrm{P}$ from plant sources has been reported to be low due to phytic acid-P [15, 28, 33-34], leading to problems of pica, infertility and haemoglobinuria in animals.

The $\mathrm{Mg}$ requirement of milch buffalo yielding $10 \mathrm{~kg}$ milk per day is $27.0 \mathrm{~g}$ (Table 2), whereas, feeds and fodders fed in that area provided $30.16 \mathrm{~g}$ of $\mathrm{Mg}$ per day. The availability $\mathrm{K}(181.29 \mathrm{~g})$ from the feed sources was adequate to meet the daily requirement of the animals (Table 2). Sodium (46.42 g) was found to be adequate in the diet of the animals as compound feed was regularly fed to the animals.

The availability of $S$ from the feed sources $23.12 \mathrm{~g}$ and the requirement was $27.0 \mathrm{~g}$ per day, showing a marginal deficiency for the milking buffalo yielding 10

Table 2: Macro and Micro-Minerals Requirement for a Milch Buffalo (450 kg) Producing $10 \mathrm{~kg}$ Milk (6\% fat) Per Day

\begin{tabular}{|c|c|c|c|c|c|c|c|c|c|c|c|c|c|}
\hline Attribute & $\begin{array}{c}\text { Tentative } \\
\text { daily } \\
\text { DMI (kg) }\end{array}$ & $\begin{array}{l}\mathrm{Ca} \\
\text { (g) }\end{array}$ & $\begin{array}{l}P \\
\text { (g) }\end{array}$ & $\begin{array}{l}\text { Mg } \\
\text { (g) }\end{array}$ & $\begin{array}{l}\mathrm{Na} \\
(\mathrm{g})\end{array}$ & $\begin{array}{l}K \\
\text { (g) }\end{array}$ & $\begin{array}{l}S \\
\text { (g) }\end{array}$ & $\begin{array}{c}\text { Co } \\
\text { (mg) }\end{array}$ & $\begin{array}{c}\mathrm{Cu} \\
(\mathrm{mg})\end{array}$ & $\begin{array}{c}\mathrm{Fe} \\
(\mathrm{mg})\end{array}$ & $\begin{array}{c}\mathrm{Mn} \\
(\mathrm{mg})\end{array}$ & $\begin{array}{c}\mathrm{Zn} \\
(\mathrm{mg})\end{array}$ & $\begin{array}{c}\mathrm{Se} \\
(\mathrm{mg})\end{array}$ \\
\hline Maintenance & 13.50 & 18.00 & 13.00 & --- & --- & --- & --- & --- & --- & --- & --- & --- & --- \\
\hline Milk production & --- & 46.50 & 29.80 & 27.00 & 24.30 & 121.50 & 27.00 & 6.75 & 135.0 & 675 & 540 & 1080 & 4.05 \\
\hline Daily requirement & $13.50 \pm 0.45$ & 64.50 & 42.80 & 27.00 & 24.30 & 121.50 & 27.00 & 6.75 & 135.0 & 675 & 540 & 1080 & 4.05 \\
\hline \multicolumn{14}{|c|}{ Feedstuffs } \\
\hline Wheat straw & 5.00 & 9.30 & 2.97 & 6.45 & 3.26 & 58.43 & 6.69 & 1.29 & 10.45 & 1921 & 208 & 93.66 & 2.28 \\
\hline Oat green & 2.00 & 5.39 & 4.53 & 2.65 & 14.27 & 43.48 & 3.95 & 0.33 & 9.58 & 568 & 78 & 34.97 & 0.51 \\
\hline Berseem green & 2.00 & 22.66 & 5.76 & 6.08 & 17.76 & 45.35 & 5.12 & 0.59 & 23.90 & 543 & 71 & 46.29 & 0.29 \\
\hline Cottonseed cake & 1.00 & 1.42 & 4.34 & 2.99 & 0.36 & 7.85 & 1.40 & 0.35 & 5.87 & 122 & 12.84 & 25.09 & 0.26 \\
\hline Mustard cake & 1.00 & 4.11 & 5.74 & 2.54 & 0.49 & 8.35 & 1.98 & 0.16 & 6.91 & 174 & 34.87 & 30.73 & 0.28 \\
\hline Wheat flour & 0.50 & 0.32 & 1.14 & 0.46 & 0.08 & 1.60 & 0.53 & 0.09 & 2.09 & 128 & 19.25 & 21.94 & 0.22 \\
\hline Cattle feed & 2.00 & 11.10 & 16.29 & 9.00 & 10.20 & 16.23 & 3.46 & 1.03 & 13.31 & 757 & 106 & 60.58 & 0.58 \\
\hline Daily availability & $13.50 \pm 0.45$ & 54.30 & 40.77 & 30.16 & 46.42 & 181.29 & 23.12 & 3.84 & 72.10 & 4213 & 529.96 & 313.26 & 4.41 \\
\hline Deficit (\%) & & 15.81 & 4.74 & + & + & + & 14.37 & 43.04 & 46.59 & + & 1.88 & 70.99 & + \\
\hline
\end{tabular}


$\mathrm{kg}$ milk per day. Sulphur supplementation was necessary in the ration of the animals due to high level of Se in various feedstuffs and bioavailability of $S$ from feed sources is scanty $[5,15]$. Similarly the buffalo yielding $10 \mathrm{~kg}$ milk daily, would need $6.75 \mathrm{mg}$ cobalt per day, as per the standard requirements, whereas, feeds and fodders available in the area when fed, provide only $3.46 \mathrm{mg} \mathrm{Co}$, showing a deficiency of cobalt (Table 2).

Copper availability from traditional feeds and fodder fed to buffalo with this level of milk production, was $72.0 \mathrm{mg}$ against the requirement of $135.0 \mathrm{mg}$ per day. Due to this large deficiency, clinical and sub clinical syndromes are likely to occur. Sub clinically, the problems of rough hair coat, poor growth rate, infertility and anemia may be encountered in cows and buffaloes and neonatal ataxia (sway back) in lamb [4].

The availability of Fe from feed sources was 4213 $\mathrm{mg}$ and the daily requirement for the milch buffalo was $675 \mathrm{mg}$ per day (Table 2). The milch buffalo yielding 10 $\mathrm{kg}$ milk per day, would require $540 \mathrm{mg} \mathrm{Mn}$ per day, whereas feed sources provided $529.96 \mathrm{mg}$ (Table 2), showing a marginal deficiency of manganese.

For the milch buffalo with $10 \mathrm{~kg}$ milk per day, requirement difference for $\mathrm{Zn}$ was to the extent of $766.74 \mathrm{mg}$ per day with the traditional feeding system (Table 2). Mastitis, night blindness, parakeratosis and reproductive failure are the ailments, which may result from its deficiency $[15,35]$. The role of $\mathrm{Cu}$ and $\mathrm{Zn}$ in augmenting production and reproduction is well documented are known to have significant correlation with reproductive homones (progesterone and estradiol), as they are specific activators of enzyme systems that assists in maintaining the activity of hypophyseal hormones in blood [36]. In this context it is also worth mentioned that zinc activates the follicle stimulating hormones and leutinising hormones produced by the pituitary gland [37].

\section{Formulation of Area Specific Mineral Mixture}

Information on the actual intake of each type of feeds and fodder for a particular level of milk production was collected for individual animal, to calculate intake of various mineral elements against the requirement. Total mineral intake from feeds and fodder was compared against the requirements on dry matter basis, to identify quantitative deficiency and adequacy of minerals. Based on the degree of deficiency, area specific mineral mixture formulation was developed for the supplementing buffaloes in the South West zone of Punjab (Table 3). To enhance the usefulness of mineral mixture, chromium in the form of chelate was also incorporated in the formulation.

Table 3: Area Specific Mineral Mixture Formulation for South West Zone of Punjab

\begin{tabular}{|c|c|c|}
\hline SI. No. & Parameter & Requirement \\
\hline \hline 1. & Moisture (\%), Max. & 5.0 \\
\hline 2. & Calcium (\%), Min. & 21.0 \\
\hline 3. & Phosphorus (\%), Min. & 12.0 \\
\hline 4. & Sulphur (\%) & $2.2-3.0$ \\
\hline 5. & Copper (\%), Min. & 0.14 \\
\hline 6. & Zinc (\%), Min. & 1.30 \\
\hline 7. & lodine (\%), Min. & 0.026 \\
\hline 8. & Cobalt (\%), Min. & 0.016 \\
\hline 9. & Chromium (\%), Min. & 0.004 \\
\hline 10. & Fluorine (\%), Max. & 0.06 \\
\hline 11. & Lead (mg/kg), Max. & 20 \\
\hline 12. & Arsenic (mg/kg), Max. & 7 \\
\hline 13. & Acid insoluble ash (\%), Max. & 3.0 \\
\hline
\end{tabular}

Note: Requirements at SI. No. 2 to 13 are on moisture-free basis.

Districts under South West zone: Firozpur, Faridkot, Mansa, Moga, Muktsar, Bathinda, Sangrur.

\section{CONCLUSION}

From the present study, it was evident that the ration of dairy animals yielding $10 \mathrm{~kg}$ milk per day in the South-West Zone of Punjab was found to be deficient in $\mathrm{Ca}, \mathrm{P}, \mathrm{S}, \mathrm{Co}, \mathrm{Cu}$ and $\mathrm{Zn}$. Therefore, it is necessary to supplement these minerals by formulating the area specific mineral mixture, using highly bio-available mineral salts to meet the requirement of dairy animals, for improved productivity and reproduction efficiency.

\section{ACKNOWLEDGEMENT}

The authors are grateful to the management of National Dairy Development Board of India, for providing necessary facilities and financial support to carry out this study.

\section{REFERENCES}

[1] Bhanderi BM, Garg MR, Goswami A, et al. Study on availability of various macro and micro-minerals in lactating buffaloes under field conditions of Sabarkantha district of Gujarat. J Buffalo Sci 2013; 2(1): 12-17. http://dx.doi.org/10.6000/1927-520x.2013.02.01.3

[2] Saijpaul S, Singh P, Sikka SS, et al. Quality assessment of mineral mixture and chelated minerals available in the market. Anim Nutr Feed Tech 2012; 12: 83-90. 
[3] McDowell LR, Conrad JH, Glen Hembry F, et al. Minerals for Grazing Ruminants in Tropical Regions. Animal Science Department, Centre for Tropical Agriculture, university of Florida, The U.S. Agency for International Development and Caribbean Basin Advisory Group (CBAG) 1993; pp.7-15.

[4] Underwood EJ, Suttle NF. The Mineral Nutrition of Livestock. $3^{\text {rd }}$ edn. CAB International Publishing Co., U.K 1999; pp. 5780.

\section{http://dx.doi.org/10.1079/9780851991283.0000}

[5] Garg MR, Bhanderi BM, Gupta SK, et al. A study on availability of various mineral elements in milch buffaloes. Anim Nutr Feed Tech 2011; 11: 91-102.

[6] Tourtelot HA. Geochemical Surveys in United States in Relation to Health. Environmental Geochemistry and Health. Royal Society, London 1980; pp. 113-126.

[7] Campbell MH, Miller JK, Schrick FN, et al. Effect of additional cobalt, copper, manganese and zinc on reproduction and milk yield of lactating dairy cows receiving bovine somatotropin. J Dairy Sci 1999; 82: 1019.

http://dx.doi.org/10.3168/jds.S0022-0302(99)75322-1

[8] Kearl LC. Nutrient Requirements of Ruminants in Developing Countries. International Feedstuffs Institute, Utah State University, UMC 46, Logan, Utah 84322, USA 1982.

[9] Snedecor GW, Cochran WG. Statistical Methods, $6^{\text {th }}$ ed. Oxford and IBH Publishing Company, New Delhi, India 1967.

[10] Bakshi MPS, Wadhwa M, Kaur K, Kaur J, et al. Nutritional status of animals of Western Plain Zone of Punjab. Indian J Anim Nutr 2009; 26(3): 199-203.

[11] Garcia-Gomez F, Williams PA. Magnesium metabolism in ruminant animals and its relationship to other inorganic elements. Asian-Austral J Anim Sci 2000; 13: 158-170.

[12] NRC. Mineral Tolerances of Domestic Animals, National Research Council, National Academy of Sciences, Washington, DC., USA 1980.

[13] Garg MR, Bhanderi BM, Sherasia PL, et al. Assessment of macro and micro-mineral status of milch animals for developing area specific mineral mixture for Bharatpur district of Rajasthan. Anim Nutr Feed Tech 2008a; 8: 53-64.

[14] Singh KK, Nag SK, Pailan GH, Kundu SS, Garg MR, Bhanderi BM, et al. Sodium and potassium contents of some common forages. Indian J Anim Nutr 2002; 19: 378-380.

[15] McDowell LR. Minerals in Animal and Human Nutrition. Academic Press. San Diego, CA 1992; pp. 49-51.

[16] Das A, Ghosh TK, Haldar S, et al. Mineral distribution in soil, feeds and grazing cattle of different physiological stages in the red laterite and new alluvial agro climatic zones of West Bengal. Indian J Anim Sci 2003; 73: 448-454.

[17] Tiwari MK, Tiwari DP, Mondal BC, Anil Kumar, et al. Macro and micro-mineral profile in soil, feeds and animals in Haridwar district of Uttarakhand. Anim Nutr Feed Tech 2007; 7: 187-195.

[18] Harmon RJ, Torre PM. Copper and zinc: Do they influence mastitis? Proc. National Mastitis Council 1994; pp.54-65.

[19] Donna M, Amaral-Phillips A, George Heersche J, et al. Role of Nutrition on Reproductive Performance. Cooperative Extension Service, University of Kentucky, College of Agriculture. ASC-138 1997.

[20] Phillippo M, Humphries WR, Atkinson T, Henderson GD, Garthwaite $\mathrm{PH}$, et al. The effect of dietary molybdenum and iron on copper status, puberty, fertility and oestrus cycles in cattle. J Agr Sci 1987; 109: 321-336. http://dx.doi.org/10.1017/S0021859600080758
[21] Bremmer I, Humphries WB, Philippo M, Walker MJ, Morrice $\mathrm{PC}$, et al. Iron induced copper deficiency in calves: Dose response relationships and interactions with molybdenum and sulphur. Anim Prod 1987; 45: 403-414.

\section{http://dx.doi.org/10.1017/S0003356100002890}

[22] Youssef FG, McDowell LR, Brathwaite RAl, et al. The status of certain trace minerals and sulphur of some tropical grasses in Trinidad. Trop Agr 1999; 76: 57-62.

[23] Miltimore JE, Mason JL. Copper to molybdenum ratio and molybdenum and copper concentrations in ruminant feeds. Can J Anim Sci 1971; 51: 193-200. http://dx.doi.org/10.4141/cjas71-026

[24] Tiffany ME, McDowell LR, O'Connor GA, Margin FG, Wilkinson NS, Cardoso EC, Percival SS, Rabiansky PA, et al. Effects of pasture applied biosolids on performance and mineral status of grazing beef heifers. J Anim Sci 2000; 78 : 1331.

[25] Nelson J. Review of trace mineral chelates and complexes available to the feed industry. Western Nutrition Conference, Winnipeg, Manitoba 1988; p. 1

[26] NRC. Nutrient Requirements of Dairy Cattle, $7^{\text {th }}$ revised ed. National Research Council, National Academy of Sciences, Washington, DC., USA 2001.

[27] Ramana JV, Prasad CS, Gowda NKS, Ramachandra KS, et al. Mineral status of soil, feed, fodder and blood plasma of animals in northern dry and northern transition zones of Karnataka. Indian J Dairy Sci 2001; 54: 40-46.

[28] Garg MR, Bhanderi BM, Sherasia PL, et al. Assessment of adequacy of macro and micro-mineral content of feedstuffs for dairy animals in semi-arid zone of Rajasthan. Anim Nutr Feed Tech 2005; 5: 9-20.

[29] Nickels CF. Micronutrients and immune response. In Proc: Montana Nutrition Conference, Bozeman, Montana 1994; p. 31.

[30] Kidd MT, Ferket PR, Qureshi MA, et al. Zinc metabolism with special reference to its role in immunity. World Poul Sci J 1996; 52: 309-324.

http://dx.doi.org/10.1079/WPS19960022

[31] Maas J. Relationship between nutrition and reproduction in beef cattle. Vet Clinics North Am: Food Anim Prac 1987; 3 : 633-646.

[32] Duffy JH, Bingley JB, Cove LY, et al. The plasma zinc concentration of nonpregnant, pregnant and parturient Hereford cattle. Austral Vet J 1997; 53: 519-522.

[33] McDowell LR, Arthington JD. Minerals for Grazing Ruminants in Tropical Regions. $4^{\text {th }}$ edn. Animal Science Department, Centre for Tropical Agriculture, university of Florida 2005 pp. 33-34.

[34] Garg MR, Bhanderi BM, Sherasia PL. Macro and micromineral status of dairy animals in hilly zone of Kerala. Anim Nutr Feed Tech 2008b; 8: 13-23.

[35] Singh SV, Pachauri SP. Zinc, immunity and mastitis, Pashudhan 2001; 16: 1 .

[36] Arora SP. Zinc and vitamin A relationship in metabolism. In TEMA4 (Eds. Gawthorne, J.M. et al.). Perth, Australia: Springer- Verlag, Berlin, New York 1981; p. 572.

[37] Balaraman N. Minerals in Animal Nutrition. National Dairy Research Institute, Karnal, Haryana 2000. 